\title{
The New Men and the Universities in East Africa
}

\section{by Adam Kuper*}

I. Modern Africa believes in salvation through education.

At the simplest level one finds the equation Education = Civilization = Christianity = Salvation, and in many African languages the same word means both teacher and priest, both attending school and attending church, both learning and praying. At the very highest levels of the state there is the same faith in the sacralizing power of education. The political leader addresses the party faithful in a neo-academic gown (often formal party uniform), and takes as his proudest title the doctorate bestowed by the Southern Baptist College. With the coming of independence, there was a very general hope that education would also deliver wealth, and a widespread feeling that education legitimated the new governments' leaders.

The fifties and sixties saw an extraordinary expansion in Africa's educational systems, an expansion powered by grass-root demand. In $1968,84 \%$ of Africa's population was illiterate, and this was still the highest proportion in the world. However, between 1950 and 1966 the number of students in Africa had increased from $8 \frac{1}{2}$ million to 27 million in primary education, from $\frac{3}{4}$ million to 4 million in secondary education, and from 71,000 to 334,000 in tertiary education. (1)

There is now a certain disillusionment in government circles. Education is increasingly expensive, and the goal of universal functional literacy has receded

* Adam Kuper is a lecturer in Social Anthropology at University College, London.

(1) UNESCO Statistical Yearbook, 1969. 
beyond the horizon. Moreover, there is little sign that the investment has paid off in economic terms. The educated are also the unemployed, and the Universityeducated are employed by the government itself.

However, the individual who becomes educated is not disenchanted. The goal in this game is sufficient education to acquire money, status and power, which means a job in the bureaucracy. Graduates in medicine and agriculture aim at administrative jobs, for the end of all education is a desk in a government office. And while graduates are squeezed year after year into already top-heavy bureaucracies, expatriates man the secondary schools and up-country hospitals.

Kenya may stand as a typical example of what the structure looks like. In Kenya $60 \%$ of the appropriate age group are in the 7-year primary course. However only $12 \%$ of primary school-leavers find places in official secondary schools, and these schools cope with only $7 \%$ of the appropriate age-group in their 4-year presixth form programes. The bottle-necks into the sixth form and then into the university are also very tight. In Eastern Africa as a whole, in $1966,0.2 \%$ of all students were in universities, as against a world average of $4.6 \%$. The absolute number of Kenyan university students studying in East Africa today is under 3,000.

Thus the educational pyramid narrows very sharply indeed. The mechanisms of selection along the route are relative success in examinations and ability to pay the fees. There are very few scholarships, and fees are substantial when set against average incomes. But there is another point to be noted about the pyramid: the higher sections are substantially more costly than the lower. The educational budget as a whole is often as much as 20 to $25 \%$ of central government revenue in Africa, and the universities take a large percentage of this. In Kenya the handful of university students consume $13 \%$ of the educational budget. In Nigeria it was estimated before the civil war that the country's 5 universities cost as much as its 266 teachers' training colleges or its 1,245 secondary schools. The universities are favoured, and they are very expensive, partly because they are residential and because they are highly dependent on expatriate staff. The distinguished economist and educationalist, W.A. Lewis, remarked scathingly, "African educators ... have loaded on the backs of their tax- 
payers, who are among the poorest in the world, the most expensive universities in the world outside North America". (1)

The emphasis on the huge enterprise in education is on these universities, which are of good international standing, which cost fantastic sums in poor countries, and which train a tiny minority ... For what? In East Africa, at least, for government jobs. But since the economy is comparatively stagnant, and few new jobs are opening up (the expatriate officials are soon replaced) new jobs to absorb graduates must often be created on a Parkinsonian basis. Today one may find two or three graduates in a small office doing one man's job, having enjoyed a good education a huge cost to others so that they may become an even greater drag on the economy after graduation. One wonders today whether the university exists to supply the bureaucracy, or the bureaucracy to employ the graduates.

II. African education may be seen as a machine for producing graduate bureaucrats. The rest are dropouts. The characteristics of the student body are therefore of considerable interest, and this is a subject which visiting sociologists have found easy to study, with the help of captive student classes, and which has been reported on from many parts of Africa. (2) The picture is fairly consistent. The students come from poor but above average backgrounds; and some observers have already noted signs of elite closure. They are westernized in clothes, recreations, religion

T1 Cited by Godfrey, in his excellent paper "The Economics of an African University", Journal of Modern African Studies, 1966, vo1.4 no.4, pp.435-55.

(2) See e.g., Remi P. Clignet and Philip Foster, "Potential elites in Ghana and the Ivory Coast: a preliminary comparison", American Journal of Sociology, Vo1.70, pp. 349-62. J.E. Goldthorpe, "An African elite: a sample survey of fifty-two former students of Makerere College in East Africa", British Journal of Sociology, 1955, Vol. 6, pp. 31-47; Gustav Johoda, "The Social Background of a West African Student Population". British Journal of Sociology, 1954, Vo1. 5, pp. 355-65, Vol. 6, pp. 71-9; Pierre van den Berghe, "An African E1ite Revisited", Mawazo, December 1968, Vol. 1, No. 4. 
and aspiration. And they overwhelmingly want to go into safe civil service jobs and not into politics. Their attitude to civil service versus political careers is nicely summed up in a table (below) by Barkan. (1) This illustrates the relationship between the students' self-image and his image of politicians and civil servants respectively.

The students are cynical about politics and concerned with security - not only for themselves, but also for a11 those who are dependent upon them. Many also believe that the civil servant may be in a position to help the country despite the "stupid" - i.e. comparatively uneducated - politicians .

Stereotypes held by East African University Students

Cabinet Minister

$\begin{array}{ll} & \begin{array}{l}\text { Wasteful } \\ \text { Subservient }\end{array} \\ \text { Permanent Secretary } & \text { Intelligent } \\ & \text { Reliable } \\ & \text { Effective }\end{array}$

Self-Image Wasteful

Intelligent

\section{KENYA} Opportunistic Opportunistic Opportunistic Reliable Honest

$$
\mathrm{N}=121
$$
Ideological Reliable Honest

\section{Subservient \\ Inte11igent \\ TANZANIA} Was teful Proud

Inte11igent Reliable Effictive

\section{Intelligent} Reliable Hones $t$

$$
\mathrm{N}=367
$$

Intelligent Reliable Hones $t$ Generous $\mathrm{N}=260$

Students do from time to time come into violent conflict with governments in Africa, and I want to look

(1) Joel D. Barkan "What Makes the East African Student Run?" Transition 1968, Vo1. 7, No. VI, pp. 26-31. This was the last edition of Transition to appear before obote arrested the editor. Speculation at the time was that a contributory cause of this action was the advertisement for Barkan's piece on Transition's cover - a banner reading "Over $1200 \mathrm{E}$. African students think Cabinet Ministers are OPPORTUNISTIC, WASTEFUL, PROUD AND SUBSERVIENT". 
at the circumstances of these conflicts, for this problem is crucial to my contention that African students are to be viewed as a presumptive elite in a bureaucratic state. For the conflict to occur with the governments which will soon employ them, one of three conditions must be met:

1. There must be a serious threat of unemployment. This is particularly obvious in the French-speaking states, where failure-rates in the universities are high. The possibility of unemployment is thus brought home to the student while he is still at the university. The cris is in Kinshasa, where about 30 students were killed on June 4, 1969, occurred against a background where, in some faculties, $75-90 \%$ of all students were being failed in their examinations. (1) In the Anglophone universities, by contrast, as indeed in England, it is virtually impossible to fail. Once in, one can normally be assured of a degree. This is a powerful spur to compliance.

2. The anticipation of elite status is frustrated the student is told he is not yet one of the privileged, that he is a child and must take orders. This is so violent a shock to the student, basking in his anticipated elite status, that he is moved to react strongly. In Dar-es-Salaam the students went on strike against a government decision to make them do national service, involving manual labour or periods of low remuneration in bush stations. The Kenya students struck when the government refused to allow them to invite Oginga Odinga to speak to them and Kenyatta made a speach stigmatising al1 "law-breakers", a category in which he included "university students and their lecturers who dabbled in politics ... prostitutes ... and noncitizens".

These are great provocations to students, but the interesting fact is that the government can coerce them readily - because the students are mainly on government grants and look forward to the realization of elite status in government service. Thus in Kenya after being humiliated, brutally assaulted by special troops and rusticated, all the students who were permitted to do so signed documents abasing themselves before

11) Georges H. Nzolgola, "Confrontation in CongoKinshasa", Mavazo, December 1969, Vo1.2, No.2. 
3. The elite is differentiated and divided, and the section out of power controls the university, which is to a considerable extent run by local people. These conditions are not met in most African states, but they were in Sudan, where the university became the main base for the coup which overthrew the military regime in October 1964. (2) Ethiopia may yet supply a second example, despite the fact that after the troubles of $1960 \mathrm{Haile}$ Sellassie sent a message to the President of the University College: "You are to teach three things. Discipline and discipline and discipline". (3)

III. To review the main features of the situation: Africa has an enormous awe for education; and it has spent huge sums, considering its resources, on creating western-type educational structures of high quality. These are broad at the base and very narrow at the top, but the greatest emphasis - financially and in publicity is placed on the pinnacle, the univeristy. The students are committed to security and see themselves, correctly, as embryo civil servants. The whole system is of doubtful value in promoting economic growth, certainly when its cost is weighed.

If this is correct, then the main function of the entire educational structure, particularly the university, is the creation of an elite. The function is to be found in the product - the graduate who takes a government job and earns more in a year (in the worn but stil1 shocking and accurate phrase) than a peasant or worker earns in a lifetime. This consequence was naturally anticipated by the Oxbridge-educated colonial planners, but they saw nothing unacceptable in this, any more than do most of their Makerere-educated successors.

71) See Africa Report, March/Apri1 1969, pp. 10-14, "Kenya and Uganda : When does Dissent become Sedition?" (2) Robert W. Crawford, "Sudan: the Revolution of October 1964", Mawazo, December 1967, Vol.1. No. 2.

(3) Richard Greenfie1d, Ethiopia, London : Pal1 Mall Press, 1965, especially pp. 365-70, 414-16. 
A subsidiary function is to reconcile the nonelite to the discrepancy in status and rewards by holding out the possibility - to themselves or their children of becoming members of the elite through the apparently merit-rewarding channels of education. The ideological support for education (its putative link with development, with Christianity, with spiritual power) serves the same purpose. It provides a charter for the status of the elite, and legitimates this status both for the elite and for the body of the population.

Note that changes in the content of education (e.g. Africanization" of the syllabus) are of marginal significance. The structure is the message. This presupposes a mode 1 of the African state where the main cleavage is between elite and masses, a model of ten proposed but also of ten rejected. The objections to it are usually reducible to one fundamental objection - that the crucial cleavages are ethnic, and that this over-rides the horizontal division. The member of the elite is loyal to his "tribe", united by various ties with its poor members, and guided by ancestral values as much as by the western values which the elite appears to exemplify.

I consider these objections to be superficial. There is evidence that the elite forms a unitary social group in which ethnic ties are of secondary importance, except when members of the elite rely upon ethnic support in competition for scarce rewards open only to elite members. (1) Ancestral values are unlikely to survive 16 formative years in boarding establishments organised to inculcate very different values, and the product of the educational system is, of course, not accepted by the peasants as one of themselves. This point was made movingly by Obote - "... everywhere in Uganda, if a secondary school-boy in particular, or even a University graduate attempts to settle in the rural area and to do what the mass of the people engaged in doing - farming whispers ascending to unspeakable innuendoes and songs disparaging to the character of such a person, are all a certainty. The parents, the clan, neighbours and various others will begin to say 'So and so's son has not got a job because of his character or because he

(1) See P.C. Lloyd, Africa in Social Change, Penguin Books, 1967, pp. 151-2; Introduction to The New Elites of Tropical Africa, Oxford University Press, 1966. 
has no brains'. So the educated lad flees from the rural area and rushes to town ...". (1)

My argument departs also from the more sophisticated plural model, which derives historically from a consideration of the colonial situation, and which posits differential political incorporation on an ethnic basis as the fundamental principle of the society. (2) This is a powerful model for the analysis of colonial and settler states, but it does not seem equally successful in the analysis of post-colonial societies, where the elite is always drawn from many indigenous ethnic groups, though one may be dominant at any time. Nevertheless a consideration of the colonial situation is necessary. There one had to be white to rule - now one must be educated in the western sense, i.e. as good as white.

I am not arguing a simple continuity with the colonial social structure; the introduction of an indigenous elite differentiated from the governed by education rather than ethnic origin involves many changes in the structure of society. For a number of reasons it releases considerable creative forces, while at the same time introducing a new and fundamental instability, because the elite will always divide in political competition for the scarce rewards. However, I am arguing that this continuity is fundamental, and that the differences depend on the mode of recruitment - education rather than colour. My emphasis thus differs from those who stress continuity with "traditional elites". This may sometimes exist as a continuity of personnel; some symbols may also be taken over; but the function of the elite, its relationship to the governed, its mode of recruitment and its life-style exhibit a more direct continuity with the colonial elite. Soon Africa's elites will be urban, educated, English and French speaking, and largely self-perpetuating; while the mass of the population will be poor, uneducated and disenfranchised peasants, relying on ethnic patronage for any advantages.

T1 See A. Milton Obote, "Policy Proposals for Uganda's Educational Needs", Mawazo, December 1969, Vo1. 2. No. 2. (p.4).

(2) See especially J.S. Furnival1, Colonial Policy and Practice: A Comparative Study of Burma and Netherlands India, Cambridge University Press, 1948; and Leo Kuper and M.G. Smith (eds.). Pluralism in Africa, University of California Press, 1969. 
Both classes, accepting the ideology of education will accept the justice of the system, which is itself a product (as they are) of the educational structure. Only the emergence of large urban unemployed groups with some education (but not enough)

I want to stress in conclusion that the features I have noted are not peculiarly African. One is reminded of Michael Young's prophetic book, The Rise of The Meritocracy, or, more directly, of many parallel tendencies in Europe. It might be objected that there is a significant difference, since elites in western countries are functionally differentiated, while in Africa commerce is in many countries predominantly in expatriate hands, and the professions offer limited scope. This is true, but seems less significant when one considers the growing employment power of the super-corporations, with their own quasi-civil services. Perhaps, in the pursuit of equality of opportunity, the characteristic modern society is everywhere creating the universal new elite of the "educated". At the least, modern universities are now the functional equivalents of the medieval church, less successful, perhaps, as moral guides; as good, or better, at arming the rulers with self-righteousness; and certainly unequalled in handling the Julian Sorels. 